\title{
The Perception and Attitude of the Society toward Funeral Ritual
}

\author{
$1^{\text {st }}$ Veronika E. T. Salem \\ Sosiology Education Department \\ Fakulty of Social Science, \\ Universitas Negeri Manado \\ Manado, North Sulawesi \\ veronike@yahoo.com
}

\author{
$4^{\text {th }}$ Zoni Henki Singal \\ Sociology Study Program \\ Faculty of Social Sciences, \\ Universitas Negeri Manado \\ Manado, Indonesia \\ henkisingal09@gmail.com
}

\author{
$2^{\text {nd }}$ Maryam Lamadirisi \\ Sociology Education Department \\ Faculty of Social Sciences \\ Universitas Negeri Manado \\ Manado, Indonesia \\ maryamlamadirisi@unima.ac.id
}

\author{
$5^{\text {th }}$ Ferdinand Kerebungu \\ Sosiology Education Department \\ Fakulty of Social Science \\ Universitas Negeri Manado \\ Manado, Indonesia \\ ferdinandkerebungu@unima.ac.id
}

\author{
$3^{\text {rd }}$ Abdul Rasyid Umaternate \\ Sosiology Education Department \\ Fakulty of Social Science, Manado \\ State University \\ Manado, North Sulawesi \\ rasyidumaternate@unima.ac.id
}

\begin{abstract}
The society of New Tompaso One in New Tompaso subdisctrict is the part of Minahasa that has the tradition that has been done over time. The process of funeral ritual is ow different from the one they used to have in the past, as happened in New Tompaso One. The aim of this research is to describe and analyze the perception formed from the series of funeral ritual activities in New Tompaso One Village. Qualitative method was used for this research. Data collection technique was done through observation, interview and documentary collection. Research finding finds that society perception and attitude towards funeral ritual has religious and social purposes by its time and space dimension.
\end{abstract}

Keywords-Perception, Attitude, Society, Funeral Ritual

\section{INTRODUCTION}

Society of New Tompaso Sub-district, South Minahasa Regency, is a part of Minahasan society, has cultures that have been kept and developed over time. One of those cultures is funeral ritual. Besides, there are also other ritual such as new house ritual, rice harvesting ritual, traditional wedding ritual and so on.

From those rituals, funeral ritual draws the family nuance, traditional obligation, moral, and binding value among relative or society of the village where one has passed away in. This picture can be seen since one of family ember passes away, so the relative, neighbor and society member of the village would come over and pray together before taking care of the corpse, and do some other preparation for funeral.

Minahasa' culture in the past, approximately in 60 s until 80 s, was very strong in terms of traditional culture. If one of the society passes away, the process of funeral ritual will be influential to the activities of the society. All of society totally pay attention to distraught family, there should be no other activities such as: farming, feeding the cow etc. If they already did these kind activities while someone passed away, it is a must that they have to finish their job quicker and go back home in order to together with the society help the distraught family.

In the past traditional funeral ritual, before the burial congregation member, society, and relatives that are generally in Minahasa and particularly in New Tompaso One would gather to pray together in the comforting night (also called one night) together with the religious prominent figures which is the priest and congregation guru. After the praying, the society will not be directly go back home but will stay; sing religious song and have recreation in order to comfort the distraught family. As long as the corpse is still in the house, there would be no laughter or music heard from surroundings even by radio or tape as the existed media at the time.

The philosophy or opinion of Minahasan people about life, can be known by their language expression that has been kept over time wherever they would be. Language expression meant by $\mathrm{H}$. Taulu, was used in various occasion, in joy or grief such as: Male'o-Le'osan (being good to one another), Mawerel-werenan (Take care and respect to one another), as well as Ma'esa-'esaan (be united), Taulu (2001:37). Since this language expression contains the philosophy of Minahasan people, to live side by side in joy as well as in grief. Sam Ratulangi has specifically formulated this life philosophical expression into a concept of an oriented cultural value of Minahasa, i.e., "Ti Tou Timou Tou", which means man live to humanize other [1].

It terms of what Minahasan people believe in, there is thought about divine power, yet they also think about the way of divine presence, the evil and good spirits. For Minahasan people, believing the spirits, especially the spirit of the dead is called "Mukur". It is believed that Mukur is still among living people, and the evil spirit of the dead, alters human being, while the good spirit of the dead, can be asked to help those who are in need [2]. The presence of 
"Mukur" is believed revealing themselves through voice or face of the possessed one. This situation happens when a member of family is in difficulty and grief. The face or voice that changes, sounds similar to the dead's. Thus, the message of "the mukur" would surely be obeyed by the family who had listened to it [3].

The culture and belief cannot be separated from the life of Minahasan People, according to [1], this affects the writers to include the belief element in investigating the tradition and culture in Minahasa [1]. The relationship between these two aspects in ecclesiastical life shows that the attitude of Minahasan People has two sides. It means, a Minahasan undertakes the duties as congregation, but in other time, undertakes the things related to the old belief or cultural religion. The practice of old belief in living as congregation is considered as cultural obligation. One of cultural obligations, according to Sumakul, is each person in society must pay attention and activelly participate, if a family goes through hard time. So, attending distraught house has become a moral obligation to society in the village.

The interest and active participation of the society as described above, lately, have altered. It is the same as observed in Tompaso Baru One Village, Tompaso Subdistrict South Minasaha Regency. In any grief, there were no society seen take along food for the distraught family. On the contrary, the grieving family members have to prepare food and drink to fete the society who come. And so it happens if the corpse is lied down through a night or more, besides food and drink, music instrument as in joyful moment such as wedding party and other joyful party will be performed. In worship time (one night), songs will be in playlist, chronologically played from religious ones, traditional ones, dangdut and Indonesian and or wester pop songs. If there is no merry musical atmosphere, the society will slowly but surely leave the grieving family themselves to keep the eyes of the corpse until the funeral ritual.

The phenomenon happened in the evening the corpse is lied down in grieving shed, also occurred on the third day of commemoration and in "kumaus" ritual on Sunday. The environment in grieving shed was made as if the family was in joyful moment. In this context, topic about "Perception and Attitude of Society toward Funeral Ritual (Phenomenological Investigation on Funeral Ritual)" that particularly observed in New Tompaso Sub-district, South Minahasa Regency. In South Minahasa Regency, it is interesting to be raised in for of research to depict the "perception and attitude of the society.

\section{RESEARCH METHODS}

This research uses qualitative approach. According to [4], qualitative research is a research that aims to comprehend the phenomenon about what is experienced by research subject; attitude, perception, motivation, action etc. Holistically, and with descriptive way in the form of words and language, in certain natural context by utilizing various scientific methods. Data collection was done through observation, interview and documentation. In the process of data analysis, researcher depends on coding procedure as emphasized by [5] that through 3 coding processes: Open coding, axial coding and selective coding.

\section{RESULTS AND DISCUSSION}

\section{A. The Perception of Society towards Funeral Ritual}

Death has important mening to the life of Minahasan people. Therefore, this phenomenon is followed by a ritual that has rooted in the community. Funeral ritual of a society member cannot be separated from the opinion about the ritual value. If it is compared to the way of funeral ritual in the past, it is way different. The funeral ritual in the past contains lots of ancient belief; animism. This belief colors the action, attitude, symbols and objects. As described above, for there is element of animism, the family has to do the ritual for instance putting the clothes of the dead that he or she used to wear when he or she was alive, goods that relate to gender (perfume, hair gel, watch, shoes, slipper, cigarette for man and gold ring, bracelet, favorite goods for woman) into the chest, for it has deep meaning that the spirit of the dead has what he or she needs all in the chest. Animism as in funeral ritual, either society or family is forbidden to wear red clothes; it has to be the black ones. It means, in general point of view if someone comes over in black to show condolence and follow the funeral ritual, which led by a priest, whether in first night, second night or third night (minahasan terms) it is untruthful to wear red but black ones, because in general point of view, wearing black is a symbol of grieving to the family and it is a symbol of being a part of family's grief. No one was in red, for if it was, he or she would be considered as disrespectful to the grieving family.

According to the theory of symbolic intercationist in comprehending the social phenomenon or individual social action states that in general, there are six basic assumption use in the context of symbolic interactionist: (a) human's behavior has meaning behind its appearance; (b) Humanity sense source needs to be sought on human's social interaction; (c) human society is a holistic process, inseparable, not linear, not estimated; (d) human's behavior occurs based on phenomenological interpretation, which occurs on purpose, meaningful, and aim not based on mechanical and authentic process; (e) Mental concept of human is dialectic development, and (f) human's behavior is genuine and constructive [6]. The true social reality never exist in real world, but is actively created when human acts "towards the world". Human defines physical and nonphysical object based on its usage and purpose [7] and [8]. According to Hebert Mead, human always changes over time, either pertaining to him or herself and the environment, purpose, life orientation, used life symbols, regulations, tools, etc. Reference [9] ini his philosophical states that an individual responds a symbolic situation. Individual responds environment including objectivity and social object (Horton, B., 1984) in [10] and [11]. Meaning is a product of social interaction, therefore meaning does not stick to the object, but "negotiated" through language usage. This happens because the mental process of individual in social life. Mind is the ability of human in using the symbol to show the surrounding object. Mind is more of "process" rather than "structure" (structural functional point of view). Mind is the ability to understand symbol. While self is basically the ability to place someone as subject and object at once. Human's behavior in the process of interaction is not determined by external and internal factor, but human themselves with their ability of shaping the object, measure based on mmeaning and decide to do based on that meaning [9]. According to symbolic interactionist, society as an 
interactive organization that relies on mind depends on individual capacity. The principles of symbolic interaction methodology are: (a) symbol and interaction are unified; (b) because the symbol and the meaning cannot be apart from personal behavior, so subject's identity needs to be caught; (c) researcher relates symbol, identity and environment as his or her social relationship; (d) as well as recording social facts; the situation that depicts symbol and its meaning is also better to be recorded; (e) used methods ought to be able to reflect the form of its behavior and process; (f) used method ought to be able to catch the meaning behind interaction; (g) sensitizing, is to direct the agreeable thought to symbolic interaction and when it starts to enter the sphere which needs to be formulated to become more operational [12].

\section{B. The Opinion of the Society on Funeral Ritual}

Funeral ritual depicts the family nuance, traditional obligation, oral and values that bind either the family or the community where there is grief. This picture can be seen once a family member passes away, so the relative, neighbor and society member with the congregation will be coming over the house of the grieving family. The society member s are usually related in the same concord as in village concord or family concord. They come over the grieving house to prepare the shed, cook etc. The most seen togetherness is when the prepare the shed, men would be going to the garden to find bamboo for the shed, the grieving family should not do anything but to stay close to the corpse. Besides, the surrounding society will come to the grieving house in black, nobody would wear other. With togetherness in grieving house regarding to the harmony so the society might bring food as rice, egg, spices, vegetables, wood and things that would be needed for the meal of the grieving family, the society also did the shed and the tomb excavation.

The changes can be progression or deterioration. Societal elements that has change usually about social values, social norms, behavior structure, social organization, societal institution, social stratification, authority, responsibility, leadership etc. In developed or developing society, cultural and social changes are always relating to economic growth. According to Selo Soemardjan and Soelaiman Soemardi, the changes, excluding the economic changes cannot be avoided for each of the changes in societal institution will also cause the changes in other societal institution, therefore, in between societal institution is always the process of affecting each other. The changes currently seem so quick, so it is harder to know which field will change in the first place regarding to social life. Even so, generally the changes are correlated one another in terms of one element to other social elements.

\section{The Ideas of Society}

As emphasized above, that the society of New Tompaso as the part of Minahasan People, in this case, funeral ritual has obeyed the life philosophy, culture and belief of Minahasan Society. In A. F. Parengkuan's (1994:33-34) dissertation, he said that life philosophy, culture and belie often cannot be separated, although there are differences. Philosophy is often related identically to what are seen in culture, while belief is often seen as human civilization. To distinguish three of these aspects, variety of definitions about the culture itself. In Minahasan context, Parengkuan (1994) said, "life philosophy is a compass held be the Minahasan as a guide in life", while the culture relating to spiritual sides inside of someone, moral life and all of his or her social relationship. On this foundation, to Minahasan, belief is related to spiritual side which is someone's supernatural experience.

The life philosophy about life, to Minahasan, can be noticed from language expression that they have kept over time, wherever they were. Language expression was used in varied occasion, either in joy or in grief, such as: Male'oLe'osan (well-behaved to each other), Mawere-werenan (take care and respect one another), and Ma'esa-'esaan (unified). Since this expressions contain philosophy so each one of Minahasan, to live alongside and to have good manner to everyone in joy or grief. Sam Ratulangi has specifically formulated this life philosophical expression into a concept of an oriented cultural value of Minahasa, i.e., "Ti Tou Timou Tou", which means man live to humanize other [1].

It terms of what Minahasan people believe in, there is thought about divine power, yet they also think about the way of divine presence, the evil and good spirits. For Minahasan people, believing the spirits, especially the spirit of the dead is called "Mukur". It is believed that Mukur is still among living people, and the evil spirit of the dead, alters human being, while the good spirit of the dead, can be asked to help those who are in need [2]. The presence of "Mukur" is believed revaling themselves through voice or face of the possessed one. This situation happens when a member of family is in difficulty and grief. The face or voice that changes, sounds similar to the dead's. Thus, the message of "the mukur" would surely be obeyed by the family who had listened to it.

\section{The Behavior of Funeral Ritual}

The characteristic of death is permanent as the end of this temporal life. Death has often become a heart-breaking thing in such emotional way to those who face this situation or for those who are left by the beloved ones.

The view about death has changed. In the past, death was considered more as scary thing and taboo. Nowadays, death is seen as normal process of life. The lost and death are reality that that often happen in nursing environment. Most of the nurses interact with the client and the family that experience the lost and grief.

Social change program for development stood by the change of individual behavior aspects, general behavior, value order, structure and social system in which individual is functioning. Basic assumption of this idea is and activity or program that is planned and implemented is meant to increase the quality of human. Because facing the changes happening in this global era moreover adapting to postindustrial life needs creative way of thinking and complete capability.

Modernization is a systematic process including the entire social behavior. Beside modernization as the transformation process. The most protruding aspect in societal modernization is production technique from traditional way into modern way. But it doesn't merely mean that all tradition as the source of culture will be vanished or replaced by the new one for building is the way to develop and increase the life that willing the social change. 
In attaining the modern status, traditional structure and value must be entirely replaced wiht the modern ones. Traditional and modern are oppositing concepts [13]. Reference [14] gives picture of the characteristic of modern human: (1) inclusive to new experience, (2) more independent attitude, (3) trust in science, (4) own the orientation of high mobility, (5) have long-term plan, (6) active to political regulation. (Inkeles, 1983).

In sociologic way, social changes can be classified into two group namely cultural and social structure, and the process of individual adaptation toward social change itself [15]. In line with that, the change occurs in the society can be seen from three dimension of change namely dimension of structural, cultural and interactional change (Imes and Moore) in [16]. Structural dimension, refers to the change of societal culture such as discovery in thinking (science), technological innovation, relationship with other culture that cause the ocurrence of diffusion and cultural borrow. While interactional dimension refers to the change of social relationship in society, regarding to the change in frequency, social distance, medium, rules and orders, in form of relationship.

The changes can be progression or deterioration. Societal elements that has change usually about social values, social norms, behavior structure, social organization, societal institution, social stratification, authority, responsibility, leadership etc. In developed or developing society, cultural and social changes are always relating to economic growth. According to Selo Soemardjan and Soelaiman Soemardi, the changes, excluding the economic changes cannot be avoided for each of the changes in societal institution will also cause the changes in other societal institution, therefore, in between societal institution is always the process of affecting each other. The changes currently seem so quick, so it is harder to know which field will change in the first place regarding to social life. Even so, generally the changes are correlated one another in terms of one element to other social elements.

In studying the social changes which are relatively complicated, the expert often have vagueness especially about the scope, definition limit and main aspects in that change. To avoid the difficulty, so the main factors to be known and understood is about the limit definition of the social change itself. Bruce J, Cohen, emphasizes that social change is social structure change and change in social organization. For instance, change in a sector of social life shows the alteration for change has happened in social structure and social organization. The main condition of the change is the social system in life relating to social and cultural values of the society.

\section{E. The Attitude of the Society}

In the past traditional funeral ritual, before the burial congregation member, society, and relatives that are generally in Minahasa and particularly in New Tompaso One would gather to pray together in the comforting night (also called one night) together with the prominent religious figures which are the priest and congregation guru. After the praying, the society will not be directly go back home but will stay; sing religious song and have recreation in order to comfort the distraught family. As long as the corpse is still in the house, there would be neither laughter nor music heard from surroundings even by radio or tape as the existence media at the time. If there was society wanted to listen to the news through RRI channel of the radio, the radio sound must not be heard from the grieving house, moreover play the tape loudly. If it was found that the society were playing radio or tape loudly, they would have been harshly told by the elders. It is meant for the people to respect the grieving family and psychologically partake in togetherness what the family was involed in.

This thing has been done by each generation, where in the last night before the burial, after the praying, singing together, having the cake and drink, as it was getting late, sometimes at 8 P.M the society and congregation had gone back home and it was only the grieving family left. On the other word, the family was the only one who were watching over the corpse.

Some of human actions are found aimless as in animal, or are not noticed. We involuntarily do things such as sneezing, blinking, dozing, etc. We do not chose to fear, happy, or suffer, or chose the reaction towards these feelings. As far as we know, animal behavior is totally instinctive (automatically respond or reflect the external stimulus). It is true that animal, often purposely respond things by using their brain. They seem to choose eating or sleeping or making friend or being agressive or urinating in guest room carpet. But, as far as sociology theoretical explanation by the sociologist even the behavior orders of the animal are involuntarily. They are creative and conditioned, not as a product of voluntarily making a creative decision.

Otherwise, almost every action of human is voluntary, this action is a product of thought. Almost everything that we do is the result of picking up action with certain way and not the other way. Furthermore, this is the purposed decision, or purpose oriented. We pick out one among many options, for as human we are able to be directed to the destiny or result and are able to take action to reach it.

Funeral ritual draws the family nuance, traditional obligation, moral, and binding value among relative or society of the village where one has passed away in. This picture can be seen since one of family ember passes away, so the relative, neighbor and society member of the village would come over and pray together before taking care of the corpse, and do some other preparation for funeral process.

In the past traditional funeral ritual, before the burial congregation member, society, and relatives that are generally in Minahasa and particularly in New Tompaso One would gather to pray together in the comforting night (also called one night) together with the prominent religious figures which is the priest and congregation guru. After the praying, the society will not be directly go back home but will stay; sing religious song and have recreation in order to comfort the distraught family. As long as the corpse is still in the house, there would be no laughter or music heard from surroundings even by radio or tape as the existence media at the time. If there was society wanted to listen to the news through RRI channe; of the radio, the radio sound must not be heard from the grieving house, moreover play the tape loudly. If it was found that the society were playing radio or tape loudly, they would have been harshly told by the elders. It is meant for the people to respect the grieving family and psychologically partake in togetherness what the family was involved in. 
From things described above, funeral ritual draws the family nuance, traditional obligation, moral and values that bind either the family or the community where there is grief. This picture can be seen once a family member passes away, so the relative, neighbor and society member with the congregation will be coming over the house of the grieving family. The society member s are usually related in the same concord as in village concord or family concord. They come over the grieving house to prepare the shed, cook etc. The most seen togetherness is when the prepare the shed, men would be going to the garden to find bamboo for the shed, the grieving family should not do anything but to stay close to the corpse. Besides, the surrounding society would come in black to the grieving house, nobody would wear other. In togetherness with the family in the grieving house regarding to the harmony so the society might bring food as rice, egg, spices, vegetables, wood and things that would be needed for the meal of the grieving family, the society also did the shed and the tomb excavation.

The philosophy of life or opinion of Minahasan people about life, can be known by their language expression that has been kept over time wherever they would be. Language expression meant by $\mathrm{H}$. Taulu, as used in various occasion, in joy or grief such as: Male'o-Le'osan (being good to one another), Mawerel-werenan (Take care and respect to one another), as well as Ma'esa-'esaan (be united), Taulu (2001:37). Since this language expression contains the philosophy of Minahasan people, to live side by side in joy as well as in grief. Sam Ratulangi has specifically formulated this life philosophical expression into a concept of an oriented cultural value of Minahasa, i.e., "Ti Tou Timou Tou", which means man live to humanize other. (N. Kalangie, 1993:163).

\section{CONCLUSION}

From the explanation above, can be concluded that the perception of the society towards funeral ritual can be known by their language expression such as: Male'oLe'osan (being good to one another), Mawerel-werenan (Take care and respect to one another), as well as Ma'esa'esaan (be united) that contains the philosophy of Minahasan people to live side by side in joy as well as in grief which is Si Tou Timou Tumou Tou which means man live to humanize other.

\section{ACKNOWLEDGMENT}

We would like to say thanks to the Rector of Manado State University who has facilitated the research and writing of this article, also to our fellow research team and writers. Thanks also to the Committee of International Conference on Social Science (ICSS) and the Atlantis Press Publisher which has facilitated the publication of this article

\section{REFERENCES}

N. S. Kalangi, "Kebudayaan Minahasa," in Manusia dan Kebudayaan Indonesia, Koentjaraningrat, Ed. Jakarta: Jambatan, 1985.

[2] Dirjaranitra, Astronomi dan Meterologi Tradisional di Daerah Propinsi Sulawesi Utara. Jakarta: Proyek Inventarisasi dan dokumentasi Kebudayaan, Dirjen Kebudayaan Depdikbud, 1989.

[3] A. F. Parengkuan, "Kehadiran Tempat dan Peran Gereja Masehi Injili Minahasa (GMIM) Tengah Pergumulan Masyarakat Minahasa dan Bangsa Indonesia Antara Tahun 1934-1979," 1994.

[4] L. J. Moleong, Metodologi Penelitian Kualitatif. Bandung: Remaja Rosdakarya, 2011.

[5] A. Strauss and J. Corbin, Dasar-Dasar Penelitian Kualitatif: Tatalangkah dan Teknik-Teknik Teoritisasi Data. Yogyakarta: Pustaka Pelajar, 2003.

[6] B. Sukidin, "Metode Penelitian Kualitatif Perspektif Mikro," Surabaya Insa. Cendekia, 2002.

[7] R. Mulyana, Mengartikulasikan pendidikan nilai. Bandung: Alfabeta, 2004.

[8] R. Soeprapto, "Interaksionisme Simbolik perspektif sosiologi modern," Yogyakarta Averroes Press dan Pustaka Pelajar, 2002.

[9] M. M. Poloma, "Contemporary Sociology: A," Contemp. Sociol., vol. 42, p. 3, 1984.

[10] G. Ritzer, Etnometodologi dalam Ilmu Sosial. Yogyakarta: Kreasi Wacana Offset, 2015.

[11] G. Ritzer, Sosiologi Ilmu Pengetahuan Berparadigma Ganda, Cet. 11. Jakarta: Rajagrafindo Pratama, 2011.

[12] Koentjaraningrat, Pengantar Ilmu Antropologi. Jakarta: Rineka Cipta, 2002.

[13] S. P. Huntington, The clash of civilizations and the remaking of world order. Penguin Books India, 1997.

[14] A. Inkeles and L. Sirowy, "Convergent and divergent trends in national educational systems," Soc. Forces, vol. 62, no. 2, pp. 303-333, 1983.

[15] H. A. R. Tilaar, Multikulturalisme: Tantangantantangan global masa depan dalam transformasi pendidikan nasional. Jakarta: Grasindo, 2007.

[16] M. M. Soelaeman, Ilmu Budaya Dasar: Suatu Pengantar. Bandung: Rafika Aditama, 2010. 